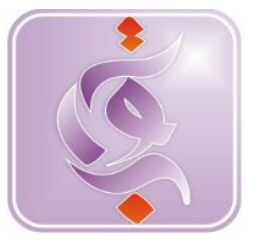

\title{
Bank Syariah Dan Penerapan K3 : Suatu Tinjauan
}

\author{
Received: 23 $3^{\text {th }}$ December 2016; Revised: 25 $5^{\text {th }}$ January 2017; Accepted: $28^{\text {th }}$ February 2017
}

\author{
Liesma Maywarni Siregar \\ Universitas Muhammadiyah Sumatera \\ Barat \\ Email: liesmamsiregar@gmail.com
}

\begin{abstract}
Abstrak: Keselamatan dan kesehatan kerja (K3) merupakan suatu kehararusan bagi sebuah organisasi. Berbagai hal dapat saja menimpa semua karyawan di tempat kerja atau di luar tempat kerja dalam rangka menyelesaikan pekerjaannya. Salah satu bentuk organisasi formal adalah lembaga keuangan syariah atau bank Syariah. Bank Islam atau selanjutnya disebut dengan bank syariah menurut Undang-Undang Nomor 21 tahun 20108 tentang Perbankan Syariah, merupakan institusi yang memberikan layanan jasa perbankan berdasarkan prinsip syariah. Prinsip syariah adalah prinsip hukum Islam dalam kegiatan perbankan berdasarkan fatwa yang dikeluarkan oleh lembaga yang memiliki kewenangan dalam penetapan fatwa di bidang syariah. Prinsip ini menggantikian prinsip bunga yang terdapat dalam sistem perbankan konvensional.Terdapat tiga alasan mengapa program keselamatan kerja merupakan keharusan bagi setiap perusahaan untuk melaksanakannya, antara lain adalah: Moral, Manusia merupakan makhluk termulia di dunia, oleh karena itu sepatutnya manusia memperoleh perlakuan yang terhormat dalam organisasi. Atau memperoleh hak untuk perlindungan atas keselamatan dan kesehatan kerja. Hukum, alasan lain yang sama pentingnya dengan moral terdapat juga alasan undang-undang ketenagakerjaan merupakan jaminanbagi setiap pekerja untuk menhadapi resiko kerja yang dihadapinya yang ditimbulkan pekerjaan. Ekonomi, alasan ekonomi akan dialami oleh banyak perusahaan karena mengeluarkan biaya-biaya yang tidak sedikit jumlahnya akibat kecelakaan kerja yang dialami pekerja.
\end{abstract}

Kata kunci : Bank Syariah K3, Ekonomi, Hukum

\section{A. LATAR BELAKANG}

Salah satu lembaga keuangan Islam yang banyak dikenal oleh masyarakat luas adalah perbankan syariah. Secara umum tujuan bank syariah adalah untuk mendorong dan mempercepat kemajuan ekonomi suatu masyarakat dengan melakukan kegiatan perbankan, finansial, komersial dan investasi sesuai kaidah syariah. Hal inilah yang membedakan bank syariah dengan bank konvensional.
Sebagai suatu lembaga yang sudah tentu bank syariah dalam operasionalnya digerakkan oleh karyawan atau pekerja. Dalam bekerja, berbagai resiko akan dialami oleh pekerja, baik yang bekerja secara ourdoor (di luar kantor) atau indoor (di dalam kantor). Berbagai resiko akan dihadapi oleh pekerja dalam rangka menjalankan roda organisasi baik resiko ringan, resiko sedang maupun resiko berat. Untuk meminimalisir berbagai resiko dalam 
bekerja, maka suatu organisasi diharapkan dapat menerapkan program K3 (Kesehatan dan keselamatan kerja). Resiko-resiko tersebut dapat berakibat fatal pada jiwa pekerja dan orang lain serta kelangsungan roda organisasi.

Oleh karena itu di buatlah berbagai ketentuan yang mengatur tentang kesehatan dan keselamatan kerja. Keselamatan kerja adalah perlindungan karyawan dari lukaluka yang disebabkan oleh kecelakaan yang berkaitan dengan pekerjaan. Resiko keselamatan merupakan aspek-aspek dari lingkungan kerja yang dapat menyebabkan kerugian pada pekerja dan juga organisasinya. Tulisan ini akan membahas sepintas mengenai Bank Syariah di Indonesia, alasan penerapan $\mathrm{k} 3$, faktor-faktor yang memengaruhi keselamatan kerja, ruang lingkup dan syarat keselamatan kerja, cara mengukur kecelakaan kerja, program pencegahan kecelakaan kerja dan program kesehatan kerja.

\section{B. Definisi}

\section{Bank Syariah}

Bank Islam atau selanjutnya disebut dengan bank syariah menurut Undang-Undang Nomor 21 tahun 20108 tentang Perbankan Syariah, (dalam Umam, 2016:1-2) perbankan syariah merupakan institusi yang memberikan layanan jasa perbankan berdasarkan prinsip syariah. Prinsip syariah adalah prinsip hukum Islam dalam kegiatan perbankan berdasarkan fatwa yang dikeluarkan oleh lembaga yang memiliki kewenangan dalam penetapan fatwa di bidang syariah. Prinsip ini menggantikian prinsip bunga yang terdapat dalam sistem perbankan konvensional. \begin{tabular}{lrr}
\multicolumn{1}{c}{ Batasan } & selanjutnya \\
mengenai & bank & syuariah \\
dikemukakan oleh & Muhamad \\
$(2015: 2) \quad$ adalah & lembaga
\end{tabular} keuangan yang usaha pokoknya memberikan pembiayaan dan jasa-jasa lainnya dalam lalu lintas pembayaran serta peredaran uang yang pengoperasiannya disesuaikan dengan prinsip syariat Islam.

Mengutip Ikatan Akuntan Indonesia (dalam Muhamad, 2015:5) bank syariah adalah bank yang berazaskan antara lain, pada asas kemitraan, keadilan, transparansi dan universal serta melakukan kegiatan usaha perbankan berdasarkan prinsip syariah. Kegiatan bank syariah merupakan implementasi dari prinsip ekonomi Islam.

2. Pengertian keselamatan kerja

Dalam menjalankan bisnisnya, bank syariah mempekerjakan pekerja. Karena melibatkan banyak tenaga kerja, maka tidak menutup kemungkinan pekerja akn berhadapan dengan berbagai masalah di tempat kerja atau diluar tempat kerja dalam rangka menjalankan tugasnya. Untuk itu, setiap organisasi termasuk lembaga keuangan syariah atau bank syariah.

Keselamatan kerja adalah perlindungan karyawan dari luka- luka yang disebabkan oleh kecelakaan yang berkaitan dengan pekerjaan. Resiko keselamatan merupakan aspekaspek dari lingkungan kerja yang dapat menyebabkan kebakaran, ketakutan aliran listrik, terpotong, luka memar, kerusakan alat tubuh. (Marliani, 2015:286).

Definisi selanjutnya oleh Suma'mur mengungkapkan 
keselamatan kerja merupakan rangkaian usaha untuk menciptakan suasana kerja yang aman dan tentram bagi para karyawan yang bekerja di perusahaan yang bersangkutan.

Menurut Simanjuntak (1994), keselamatan kerja merupakan kondisi keselamatan yang bebas dari resiko kecelakaan dan kerusakan yang mencakup kondisi bangunan, kondisi mesin, peralatan keselamatan, dan kondisi karyawan.

Mathis dan Jackson (2002) menyatakan bahwa keselamatan adalah merujuk pada perlindungan terhadap kesejahteraan fisik seseorang terhadap cedera yang berkaitan dengan pekerjaan.

Dalam bekerja, keselamatan kerja sangat erat kaitannya dengan kesalahan menusia (human error). Human error merupakan peristiwa yang pelaku penyebabnya dapat diperiksa. Human error merupakan keputusan atau perilaku manusia yang tidak tepat, tidak diinginkan yang dapt dikurangi (Sanders \& McCormick, 1992). (Erita Y. Diahsari, 2016 hal: 101).

3. Pengertian kecelakaan kerja

Adapun kesehatan kerja
menurut Mondy adalah
kebebasan dari kekerasan fisik.
Resiko kesehatan merupakan
faktor-faktor dalam lingkungan
kerja yang bekerja melebihi
periode waktu yang ditentukan.
Kecelakaan merupakan
interaksi dengan lingkungan
yang tidak membwa kemujuran,
tidak dapat diperkirakan dan
tidak dapat dihindari. Kecelakaan
berarti rendah dalam
pengharapan, kemampuan
menghindar, cenderung yang
menyebabkan kecelakaan. Ada

yang menyebut kecelakaan adalah tindakan tangan Tuhan (Sanders \& McCormick, 1992). (dalam Diahsari, 2016: 102).

\section{Alasan Penerapan K3}

Kesehatan dan keselamatan kerja merupakan bagian yang sangat penting dalam ketenaga kerjaan. Oleh karena itu di buatlah berbagai ketentuan yang mengatur tentang kesehatan dan keselamatan kerja. Berawal dari adanya undang-undang Nomor 14 tahun 1969 tentang pokokpokok ketatanegaraan yang dinyatakan dalam pasal 9 bahwa "setiap tenaga kerja berhak mendapatkan perlindungan atas keselamatan, kesehatan dan pemeliharaan moril kerja serta perlakuan yang sesuai dengan harkat, martabat, manusia, moral agama". (Marliani, 2015: 286)

Terdapat tiga alasan mengapa program keselamatan kerja merupakan keharusan bagi setiap perusahaan untuk melaksanakannya, antara lain adalah:

1. Moral

Manisia merupakan makhluk termulia di dunia, oleh karena itu sepatutnya manusia memperoleh perlakuan yang terhormat dalam organisasi. Atau memperoleh hak untuk perlindungan atas keselamatan dan kesehatan kerja.

2. Hukum

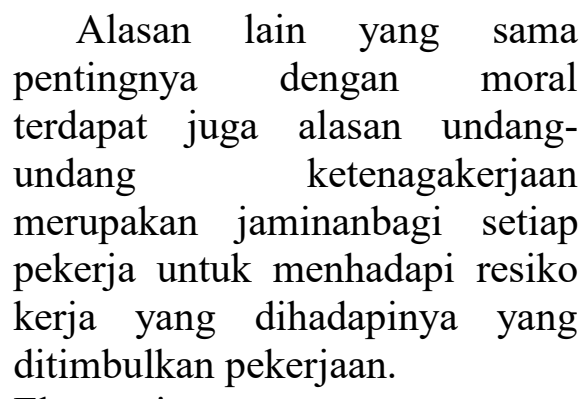

3. Ekonomi

Alasan ekonomi akan dialami oleh banyak perusahaan karena mengeluarkan biaya-biaya yang 
tidak sedikit jumlahnya akibat kecelakaan kerja yang dialami pekerja.

Dewasa ini pelaksaan keselamatan dan kesehatan kerja menjadi perhatian penting bagi berbagai organisasi, karena semakin tingginya tingkat kecelakaan kerja yang dialami para pekerja. Hal ini akan berdampak pada rendahnya produktivitas yang berakibat pada kerugian yang dialami pihak perusahaan. (Bangun, 2012: 377-378).

\section{Faktor yang Mempengaruhi Kesehatan Kerja}

Kesehatan kerja karyawan dapat dipengaruhi berbagai faktor. Menurut Kasmir (2016:277-278) Perusahaan juga harus mengelola faktor-faktor penyebeb tersebut, sehingga kesehatan karyawan tetap terjaga. Berikut faktor-faktor yang mempengaruhi kesehatan kerja, yaitu:

1. Udara

Yaitu kondisi udara di ruangan tempat bekerja harus membuat karyawan tenang dan nyaman. Misalnya diruangan tertutup perlu diberikan pendingin ruangan yang cukup. Demikian pula dengan ruangan yang terbuka diberi penutup mulut untuk kondisi udara yang berdebu.

2. Cahaya

Kualitas cahaya di ruangan juga akan mempengaruhi kesehatan karyawan. Pada ruangan yang terlalu gelap atau cahayanya kurang tentu akan merusak kesehatan karyawan , terutama kesehatan mata. Demikian pula dengan terlalu banyak cayaha.

3. Kebisingan

Suara yang ada dalam suatu ruangan atau lokasi bekerja.
Ruangan yang terlalu berisik akan memengaruhi kualitas pendengaran.

4. Aroma berbau

Seperti aroma yang kurang sedap aroma yang dikeluarkan dari zat-zat tertentu yang membahayakan, misalya zat kimia akan mempengaruhi kesehatan karyawan.

5. Layout ruangan

Tata letak ruangan sangat memengaruhi kesehatan karyawan, misalnya tata letak kursi, meja serta peralatan lainnya.

\section{E. Faktor yang Mempengaruhi Keselamatan Kerja}

Kasmir (2016:274-276) menjabarkan ada faktor-faktor yang memengaruhi keselamatan kerja karyawan, yaitu:

1. Kelengkapan peralatan kerja

Bahwa peralatan keselamatan kerja yang lengkap sangat diperlukan. Artinya semakin lengkap peralatan keselamatan kerja yang dimiliki, maka keselamatan kerja makin baik.

2. Kualitas peralatan kerja

Disamping lengkap perlengkapan kerja yang dimiliki juga harus diperhatikan kualitas dari perlengkapan keselamtan kerja. Karena akan memengaruhi keselamatan itu sendiri.

3. Kedisiplinan karyawa

Berkaitan dengan perilaku karyawannya dalam menggunakan peralatan keselamatan kerja. Karyawan yang kurang disiplin akan dalam menggunakan perlengkapan maka akan keselamatan kerjanya makin tak terjamin. Artinya timbul resiko kecelakan makin besar dan sering terjadi.

4. Ketegasan pemimpin

Ketegasan pemimpin dalam menerapkan aturan penggunaan 
peralatan kesempatan kerja. Makin tidak disiplinya pemimpin untuk mengawasi dan menindak anak buahnya yang melanggar ketentuan digunakannya perlengkapan kerja maka akan berpengaruh pada keselamatan kerja karyawan.

5. Semangat kerja

Dengan lengkapnya peralatan keselamatan kerja maka akan memberikan semangat kerja yang tinggi, merasa aman dan nyaman pada setiap karyawan.

6. Motivasi kerja

Sama dengan semangat kerja, motivasi karyawan untuk bekerja juga akan kuat jika peralatan keselamatan kerja yang lengkap, baik dan sempurna.

7. Pengawasan

Setiap karyawan harus diawasi dalam menggunakan peralatan keselamatan kerja. Jika tidak diawasi banyak karyawan yang melanggar. Pengawan dapat dilakukan dengan menggunakan peralatan seperti CCTV di tempat-tempat tertentu.

\section{F. Ruang lingkup dan Syarat Keselamatan Kerja \\ Menurut Undang- Undang} Nomor 13 Tahun 2003 ruang lingkup keselamatan kerja dalam segala tempat kerja, baik di darat, di dalam tanah, dipermukaan air, di dalam air maupun di udara, yang derada di dalam wilayah kekuasaan hukum Republik Indonesia.

Ketentuan-ketentuan menurut Undang-Undang ini berlaku di tempat kerja dimana:

1. Dibuat, dicoba, dipakai atau dipergunakan mesin, pesawat, alat, perkakas, peralatan atau instalasi yang berbahaya atau dapat menimbulkan kecelakaan.

2. Dibuat, diolah, dipakai, dipergunakan, diperdagangkan, diangkut, atau disimpan atau bahan yang dapat meledak, mudah terbakar, menggigit, beracun, menimbulkan infeksi, bersuhu tinggi.

3. Dikerjakan pembangunan, perbaikan, perawatan, pembersihan atau pembongkaran rumah, gedung atau pembengunan lainnya termasuk bangunan perairan, saluran atau terowongan di bawah tanah dan sebagainya.

4. Dilakukan usaha: pertanian, perkebunan, pembukaan hutan, pengerjaan hutan, pengolahan kayu atau hasil hutan lainnya, peternakan, perikanan dan lapangan kesehatan.

5. Dilakukan usaha pertambangan dan pengolahan: emas, perak, logam atau bijih logam lainnya, batu-batuan, gas, minyak atau mineral lainnya, baik dipermukaan atau didalam bumi, maupun didasar perairan.

6. Dilakukan pengangkutan barang, binatang atau manusia baik didarat melaului terowongan, dipermukaan air, dalam air maupun diudara.

7. Dikerjakan bongkar muat barang muatan dikapal, perahu, dermaga, dok, stasiun atau gudang.

8. Dilakukan penyelamatan, pengambilan benda dan pekerjaan lain didalam air.

9. Diputar film, pertunjukan sandiwara atau diselenggarakan reaksi lainnya yang memakai peralatan, instalasi listrik atau mekanik.

Adapun

syarat-syarat keselamatan kerja meneurut UndangUndang Nomor 1 Tahun 1970 adalah untuk;

1. Mencegah dan mengurangi kecelakaan

2. Mencegah, mengurangi dan memadamkan kebakaran 
3. Mencegah dan mengurangi bahaya peledakan

4. Memberi kesempatan jalan menyelamatkan diri pada waktu kebakaran atau kejadian-kejadian lain yang berbahaya

5. Memberi pertolongan pada kecelakaan

6. Memberi alat-alat perlindungan dari pada para pekerja. (Kasmir, 2016: 280-281).

\section{G. Faktor yang Mempengaruhi Kecelakaan Kerja}

Kecelakaan kerja disebabkan oleh dua faktor utama yaitu manusia dan lingkungan. (Kasmir:2016) ;

a. Kondisi yang tidak aman dan faktor lain yang berhubungan dengan pekerjaan kondisi tidak aman adalah salah satu penyebab utama kecelakaan. Hal - hal seperti:

1. Peralatan yang tidak terjaga dengan baik

2. Peralatan yang rusak

3. Prosedur bahaya di dalam atau disekitar mesin atau peralatan

4. Penyimpanan yang tidak aman

5. Penerangan yang tidak tepat

b. Tindakan yang tidak aman selanjutnya dapat merusak upaya terbaik sekaligus untuk meminimalkan kondisi yang tidak aman. Tapi sayangnya tidak mudah menjawab pertanyaan tentang apa yang menyebabkan hal tersebut. Karenanya, meskipun orang yakin bahwa hampir semua orang yang mudah celaka adalah orang yang impulsif.

\section{H. Program Mencegah Kecelakaan Kerja}

Diahsari, menjelaskan beberapa program yang dapat meminimalisir kecelakaan, misalnya dengan cek prosedur, pelatihan, umpan balik dan program insentif. Selain itu inspeksi meliputi monitoring, menguji, mengukur dan petrol (cek), sedang pemeliharaan mencakup perhatian pada kajian antropomentri, komunikasi, display informasi, kendali (Sanders \& McCormick, 1992).

1. Buat aturan tentang keselamatan, yaitu perusahaan membuat suatu peraturan tentang keselamatan kerja.

2. Buatkan rambu-rambu yang mudah dibaca, setelah adanya pedoman keselamatan kerja pihak perusahaan juga memasang rambu-rambu disetiap sudut yang dianggap penting.

3. Sediakan alat pengamanan kerja, di dalam bekerja sudah disiapkan berbagai alat keaman.

4. Selalu melakukan pemeliharaan alat, peralatan kecelakaan kerja harus suatu waktu secara terus menerus dijaga dan dan dipelihara.

5. Memberikan sanksi bagi yang melanggar, semacam tindakan bagi mereka yang tidak menggunakan peralatan bekerja selama bekerja.

1. Mengurangi kondisi yang tidak aman

Mengurangi kondisi tersebut merupakan garis besar pertama seorang pengusaha. Para insinyur keamanan harus merancang pekerjaan untuk menghilangkan atau mengurangi bahaya beban fisik. Sekali lagi mengurangi kondisi tidak aman dengan merancang pekerjaan dengan baik dan memiliki maneger yang mengawasi bahaya selalu menjadi prioritas utama. Kemudian pengendalian administratif. Seperti rotasi pekerja untuk mengurangi 
keterbukaan jangka panjang terhadap bahaya.

a. Mengurangi tindakan tidak aman dengan melakukan keamanan yaitu memuji karyawan, mendengarkan berbagai keluh kesah karyawan, mengunjungi daerah baprik secara teratur, memelihara komunikasi keamanan

b. Mengurangi tindakan tidak aman dengan seleksi dan penempatan. Tujuannya adalah untuk mengisolasi sifat seperti keterampilan visual yang dapat di prediksikan kecelakaan pada pekerjaan yang bersangkutan.

c. Mengurangi tindakan tidak aman melalui pelatihan. Adalah cara lain untuk mengurangi tindakan tidak aman.

2. Mengurangi kondisi yang tidak aman melalui motivasi. (Dessler, 2009 ).

\section{Cara Mengukur Kecelakaan Kerja}

Suatu persyaratan yang ditetapkan melalui Occupational and Health Act (OSHA) untuk memantau keselamatan dan kesehatan kerja, mewajibkan perusahan melakukan penctatan atas kejadian- kejadian yang berkaitan denagan kecelakaan dan kesehatan kerja. (Bangun, 2012: 280 ).

1. Tingkat kecelakaan kerja

Tingkat kecelakaan kerja atau disingkat dengan TKK adalah mengukur tinggi rendahnya kecelakaan dan peyakit yang diderita para pekerja selama setahun kerja. Tingkat kecelakaan kerja dapat dihitung dengan menggunakan rumus sebagai berikut:
Sebagai contoh, perusahaan A memiliki 400 karyawan mencatat 20 kali terjadi kecalakaan dan penyakit. Jumlah jam kerja setahun adalah $40 \times 50 \times 40=800.000$, sehingga: 5

Berdasarkan contoh tersebut terdapat 5 kali kecalakaan dan penyakit setiap 100 orang karyawan setahun.

2. Frekuensi kecelakaan

Frekuensi kecelakaan disingkat FK menggambarkan jumlah kecelakaan kerja yang terjadi setiap satu juta jam kerja (bukan dalam setahun). Digunakan rumus sebagai berikut:

Berdasarkan contoh sebelumya, frekuensi kecelakaan dapat dihitung:

25

Hasil perhitungan ini menunjukkan terjadi sebanyak 25 kali kecelakaan dan penyakit dalam satu juta jam kerja.

3. Tingkat kegawatan

Tingkat kegawatan, disingkat TK merupakan suatu pengukuran atas hilangnya jam kerja akibat kecelakaan keja. Tingkat kegawatan dapat diketahui dengan menggunakan rumus berikut:

Berdasarkan contoh sebelumya, bila jam kerja yang hilang sebesar 50 jam, maka tingkat kegawatan dapat dihitung: 62,5

Hasil perhitungan menunjukkan terdapat 62,5 kali kecelakaan kerja dan penyakit kerja..

\section{J. Program kesehatan kerja}

Upaya pencegahan kecelakaan kerja adalah suatu bagian dari fungsi tekanan seperti halnya ketidak amanan kerja. Suatu hal yang 
penting dan sebagai sebagai salah satu kewajiban perusahaan untuk menaruh perhatian atas kesehatan karyawan, baik kesehatan fisik maupun mental untuk alasan ekonomi dan kemanusiaan.

Untuk gangguan ekonomi, gangguan kesehatan karyawan akan menyebabkan menurunnya hasil kerja karyawan. Absennya beberapa karyawan karena alasan sakit akan berakibat terambatnya kegiatan reproduksi yang berdampak tidak tercapainya hasil produksi yang diharapkan.

Untuk membuat program kesehatan mental, menurut Sedarmayanti (2015:207) perlu dilakukan beberapa cara antara lain:

1. Menyediakan psikiatris untuk konsultasi

2. Bekerja sama dengan psikiatris di luar perusahaan atau di lembaga konsultasi

3. Mendidik pegawai mengenai arti pentingnya kesehatan mental

4. Mengembangkan dan memelihara program human relations yang baik.

\section{K. KESIMPULAN}

Bekerja di sektor lembaga keuangan artau bank syraiah dituntut untuk menerapkan keselamatan dan kesehatan kerja merupakan cara untuk memberikan perlindungan kepada karyawannya. Pemberian perlindungan dilaksanakan sesuai dengan peraturan perundangundangan yang berlaku. Dalam hal ini diperlukan tanggung jawab perusahaan karena bagaimanapun karyawan adalah asset perusahaan yang harus dilindungi hak-haknya, terutama dalam hal keselamatan dan kesehatan kerja.

Dapat disimpulkan bahwa kesehatan dan keselamatan kerja di tempat kerja bertujuan agar petugas, masyarakat dan lingkungan tenaga kerja selalu dalam keadaan sehat, nyaman, selamat, produktif dan sejahtera. Dan untuk dapat mencapai tujuan tersebut, perlu kemauan, kemampuan, dan kerjasama yang baik dari semua pihak.

\section{DAFTAR PUSTAKA}

Bangun, Wilson, Manajemen Sumber Daya Manusia, Jakarta: Erlangga, 2012.

Diahsari, Erita Y, Pengantar Psikologi \& Organisasi, Yogyakarta: UAD Press, 2016.

Kasmir, Manajemen Sumber Daya Manusia (Teori dan Praktik), Jakarta: Rajawali Pers, 2016.

Muhamad, Manajemen Dana Bank Syariah. Jakarta. RajaGrafindo Persada. 2015

Sedarmayati, Manajemen Sumber Daya Manusia, Reformasi, Birokrasi, dan Manajenen pegawai Negeri Sipi., Bandung: PT. Refika Aditama, 2010.

Rosleny, Marliani, Psikologi Industridan Organisasi, Bandung: Pustaka Setia, 2015.

Umam, Khotibul. Perbankan Syariah Dasar-Dasar dan Dinamika Perkembangannya di Indonesia. PT. RajaGrafindo Persada. Jakarta. 2016 